Науковий вісник НлТУ України Scientific Bulletin of UNFU

https://nv.nltu.edu.ua

https://doi.org/10.36930/40300304

Article received $29.05 .2020 \mathrm{p}$.

Article accepted 04.06.2020 p.
ISSN 1994-7836 (print)

ISSN 2519-2477 (online)

$@ \bowtie$ Correspondence author

M. L. Kopiy

marykop16@ukr.net

UDC 504:631.461,466

Б. В. Борисюк ${ }^{1}$, В. В. Швець ${ }^{1}$, М. Л. Копій ${ }^{2}$

${ }^{1}$ Житомирський начіональний агроекологічний університет, м. Житомир, Украйна ${ }^{2}$ Національний лісотехнічний університет України, м. Львів, Украйна

\title{
МІКРОБІОЛОГІЧНА АКТИВНІСТЬ У РИЗОСФЕРІ ТРАВОСУМІШЕЙ НА РЕКУЛЬТИВОВАНИХ ЗЕМЛЯХ
}

Розглянуто вплив структури та способу посіву травосумішей на біологічну активність та мікологічну структуру рекультивованого грунту на різних дослідних об'єктах. Відзначено, що між мікрофлорою та рослинами постійно відбуваються взаємовигідні біотичні зв'язки, які позначаються на зростанні чисельності основних фізіологічних груп мікроорганізмів у ризосферній зоні. Кореневі виділення рослин специфічно впливають як на розвиток мікроорганізмів кореневої зони, так і на біохімічну активність грунту. Встановлено перевагу зростання чисельності бактерій, що використовують мінеральний азот, та стрептоміцетів за варіанта травосумішей: очеретянка звичайна, грястиця збірна, конюшина червона, як при рядковому посіві, так і при посіві у розкид. Відзначено, що на дослідних варіантах травосумішей процеси мінералізації відбуваються більш інтенсивно, відповідно рівень активності мікрофлори значно вищий порівняно із проектованим складом. Емісія вуглекислого газу на дослідних ділянках у 2017 р. є вищою від контрольного варіанта, що свідчить про вищий рівень мікробіологічної активності в ризосфері дослідних травосумішей на рекультивованих ділянках. Відповідно до динаміки показників мінералізації спостерігаємо зміни показників коефіцієнта оліготрофності. Доведено, що під час розвитку агроценози дослідних варіантів за показниками мікробної біомаси переважають агроценоз проектованого складу травосумішей. Досліджено, що на порушених грунтах Яворівського та Новороздільського сірчаних кар'єрів, зростання видового різноманіття рослин сприяє також збагаченню мікологічної структури грунтів. Відзначено, що найвищою біологічною різноманітністю (50 видів) мікроміцетів 3 високою частотою трапляння Aureobasidium pullulans (23,1\%), Trichoderma lignorum (12,5 \%) характеризуються порушені землі Новороздільського сірчаного кар'єру, на яких створені мішані деревостани. Дещо менша різноманітність (43 види) характерна для мікобіоти грунтів з високою частотою трапляння Penicillium digitatum (31,5\%), Aureobasidium pullulans (18,5\%) на території Яворівського сірчаного кар'єру, де видовий склад деревостанів значно спрощений.

Ключові слова: травосуміші; рослинні угруповання; ризосфера; біологічний етап рекультивації; бактерії; мінералізація; мікологічна структура.

\section{Вступ}

Відновлення втраченої якості техноземів багато в чому визначається активністю мікробних ценозів вторинних сукцесій та мікологічною структурою порушених грунтів. Проекти біологічного етапу рекультивації земель не завжди враховують природно-кліматичні екологічні умови вторинних сукцесій та відповідальність замовника за їх технологічну ефективність реабілітації, втраченої природної якості, з часу передачі земель власнику. Внаслідок недосконалості законодавства 3 прийому-передачі рекультивованих земель, проекти та технології рекультивації земель переважно мають на меті - тільки здешевлення їх проведення. Ці обставини $\epsilon$ визначальними в наведених технологіях у проектах біологічного етапу рекультивації порушених земель.

Здебільшого біологічний етап сільськогосподарського та лісогосподарського напрямку рекультивації земель, зокрема так званий "меліоративний період", три- ває не п'ять-чотири роки, а розтягується на десятки років. Запроваджені проектами технології втрачають свою актуальність. Реабілітації грунтів на таких ділянках відбуваються під впливом сукцесійних угруповань ендемічної рослинності.

Для відновлення якості рекультивованих, після добування ільменітових руд та сірки, земель, варто мати набір технологій, які матимуть науково обгрунтовані ефективні рекомендації та відповідні критерії оцінювання екологічної ефективності технологічних прийомів реабілітації грунтів. Одним з таких критеріїв, на нашу думку, є мікробіологічна активність та мікологічна структура в ризосфері культур фітомеліорантів.

Об'єктом дослідження є рекультивація земель після видобування ільменітових руд.

Предметом дослідження є методи і засоби визначення мікробіологічної активності у ризосфері травосумішей на рекультивованих землях, що дасть змогу виз-

\section{Інформація про авторів:}

Борисюк Борис Васильович, канд. с.-г. наук, доцент, кафедра екологіï. Email: borisuk@rambler.ru Швець Володимир Васильович, аспірант, кафедра екологіï. Email: bbc11@ukr.net

Копій Марія Леонідівна, канд. с.-г. наук, асистент, кафедра екологіï. Email: marykop16@ukr.net; https://orcid.org/0000-0003-4355-5543

Цитування за ДСтУ: Борисюк Б. В., Швець В. В., Копій М. Л. Мікробіологічна активність у ризосфері травосумішей на рекультивованих землях. Науковий вісник НлтУ України. 2020, т. 30, № 3. С. 24-28.

Citation APA: Borysyuk, B. V., Shvets, V. V., \& Kopiy, M. L. (2020). Microbiological activity in the grassmixture rhizosphere on reclaimed lands. Scientific Bulletin of UNFU, 30(3), 24-28. https://doi.org/10.36930/40300304 
начити рівень ефективності проведення біологічного етапу рекультивації земель після видобування ільменітових руд.

Мета дослідження - оцінити рівень ефективності проведення біологічного етапу рекультивації земель після видобування ільменітових руд на Поліссі та сірки на Львівщині.

Завданнями дослідження є: встановлення переваг зростання чисельності бактерій, що використовують мінеральний азот, та стрептоміцетів за варіанта травосумішей; визначити на дослідних варіантах травосумішей процеси мінералізації, рівень активності мікрофлори порівняно із проектованим складом; довести розвиток агроценози дослідних варіантів за показниками мікробної біомаси у кореневмісному шарі рекультивованого грунту та лісовирощування на порушених грунтах.

Наукова новизна дослідження полягає в тому, що було вперше розроблено методику, яка дає змогу встановити перевагу зростання чисельності бактерій, що використовують мінеральний азот, та стрептоміцетів за варіанта травосумішей: очеретянка звичайна, грястиця збірна, конюшина червона, як при рядковому посіві, так і при посіві у розкид..

Практична значущість отриманих результатів зводиться до того, що розроблена методика дає змогу спостерігати зміну показників коефіцієнта оліготрофності відповідно до динаміки показників мінералізації. Відзначено, що найвищою біологічною різноманітністю (50 видів) мікроміцетів 3 високою частотою трапляння Aureobasidium pullulans (23,1\%), Trichoderma lignorum $(12,5 \%)$ характеризуються порушені землі Новороздільського сірчаного кар'єру, на яких створені мішані деревостани.

Аналіз літературних джерел. Розробляючи наукові основи грунтознавства, В. В. Докучаєв зазначав величезну роль живих організмів, і зокрема, мікроорганізмів, грибів, у формуванні грунту. Численними дослідженнями показано, що рослини впливають на життєдіяльність інших живих організмів грунту: корені рослин змінюють структуру грунту, повітряний режим, беруть участь у розкладі мінералів, є джерелом органіки для мікробіоти. Між мікрофлорою та рослинами постійно відбуваються взаємовигідні біотичні зв'язки, які позначаються на зростанні чисельності основних фізіологічних груп мікроорганізмів у ризосферній зоні. Кореневі виділення рослин специфічно впливають як на розвиток мікроорганізмів кореневої зони, так і на біохімічну активність грунту [12]. Характеризуючи інтенсивність продуктивного процесу, важливими критеріями можна вважати загальну мікробну біомасу та мікологічну структуру. Біомаса грибів у грунтовому шарі перевищує бактеріальну в усіх типах зональних грунтів. Однак у зоні безпосереднього впливу кореневої системи рослин - у ризосфері і в ризоплані, де багато екскрементованих корінням низькомолекулярних органічних речовин, різко виражене домінування бактерій над грибами [3]. Бактерії інокулюють цю зону більш активно, тоді як мікроміцети мають явний паритет у гетерогенній зоні завдяки швидшому росту гіф. Тому ріст чисельності бактерій у кореневій зоні рослин свідчить про збільшення товщі шару грунту, пронизаного коренями культивованої рослинності, а відповідно, і підвищення продуктивності. Співвідношення між чисельністю мікромі- цетів і бактерій може слугувати дієвим критерієм грунтової родючості.

Забезпеченість поживними речовинами екотопів визначається розмірністю коефіцієнта оліготрофності, менше 1 - свідчить про їх нормальну забезпеченість поживними речовинами, а здебільшого перевищення 1 вказує на певний їх дефіцит [5]. $Є$ різні думки щодо впливу видового різноманіття рослин на біологічні властивості грунту: теоретично - збільшення видового різноманіття сприяє збагаченню грунту необхідними органічними речовинами, проте дослідженнями показано, що специфічність виду рослин є також вагомим чинником впливу, поряд із різноманітністю [9].

Розглядаючи участь мікроорганізмів у кругообігу елементів живлення, найбільшу увагу звертають на Нітроген. У грунті цей елемент часто є лімітуючим фактором розвитку рослин. Нітрифікація забезпечується високоспеціалізованими групами бактерій, які дуже чутливі до змін у довкіллі та до наявності токсичних сполук. Тому оцінка потенційної нітрифікаційної активності мікробіоти дає розуміння якості грунту [11].

У нашій країні, як і на всій земній кулі, є велика площа грунтів, що підлягають рекультивації. Це і відвали гірсько-рудних розробок, і території, забруднені нафтопродуктами і т.ін. Але, на жаль, сьогодні в Україні більшість проектів із рекультивації не враховують мікробіологічні особливості у відновленні родючості грунтів. А це ставить проблему в низку важко розв'язуваних [13].

Отже, екологічний стан грунтів визначається діяльністю грунтових мікроорганізмів - високочутливих індикаторів, показників біологічної активності грунту, агентів біорекультивації [9].

\section{Викладення основного матеріалу}

Польові дослідження за темою наукової роботи виконували впродовж 2014-2017 рр. на базі Іршанського гірничо-збагачувального комбінату в межах рекультивованої земельної ділянки Лемненського родовища ільменітових руд, що розташоване на території Лісовщинської сільської ради Коростенського р-ну Житомирської обл. та впродовж 2013-2017 рр. на порушених землях Яворівського i Новороздільського сірчаних кар'єрів Львівської області.

Для досягнення поставленої мети та вирішення наукової задачі виконали польовий дослід [6] 3 таким набором варіантів:

Bapiaнm 1 - очеретянка звичайна, грястиця збірна, конюшина червона, (посів рядковий);

Bаріант 2 - костриця очеретяна, стоколос безостий, грястиця збірна, конюшина червона, (посів рядковий);

Bapiaнm 3 - очеретянка звичайна, грястиця збірна, конюшина червона, (посів урозкид);

Bаріант 4 - костриця очеретяна, стоколос безостий, грястиця збірна, конюшина червона (посів урозкид);

Контроль - конюшина червона, райграс пасовищний, грястиця збірна, вівсяниця (склад травосумішей згідно 3 проектом рекультивації на земельній ділянці Лемненського родовища ільменітових руд).

Визначення чисельності основних еколого-трофічних груп проводили загальноприйнятим методом мікробіологічних досліджень [10]. Спрямованість мікробіологічних процесів у грунті визначали шляхом розрахунку коефіцієнтів мінералізації та оліготрофності [2]. Вміст загальної мікробної біомаси визначали регідра- 
ційним методом [10]. Інтенсивність "дихання" грунту визначали абсорбційним методом Штатнова.

\section{Результати дослідження}

Враховуючи важливу роль мікроорганізмів грунту у процесах відтворення його родючості, аналіз особливостей функціонування мікробних асоціацій може слугувати важливим показником ефективності рекультивації. На відновлення структури грунту сприятливо впливає вирощування на рекультивованих ділянках сумішей багаторічних бобових і злакових трав. Значення біологічних особливостей трав полягає у тому, що сильно розгалужена коренева система розчленовує ущільнений мало структурований техноземний грунт і створює умови для формування агрономічної цінної водостійкої структури. Так, виконані дослідження в період 20152017 рр. засвідчили зростання чисельності бактерій, що використовують мінеральний азот та стрептоміцетів за складу чотирьохкомпонентної травосуміші: костриия очеретяна, стоколос безостий, грястиия збірна, конюшина червона, як при рядковому посіві - варіант 2 , так і при посіві у розкид - варіант 4 (табл. 1).
Спрямованість мікробіологічних процесів у грунті кореневої зони трав'яних рослин визначали за коефіцієнтом мінералізації (табл. 2). У 2014 р., під час закладання досліду, у грунті кореневої зони рослин на контрольному варіанті дослідної ділянки, коефіцієнт мінералізації наближається до 1, що свідчить про переважання процесів синтезу над деструкцією 0,35, на дослідних варіантах травосумішей коефіцієнт мінералізації вищий 1, тобто опосередковано можна говорити про зростання інтенсивності мінералізаційних процесів.

У наступному 2016 р. досліджень відзначено, що на всіх варіантах досліду процес синтезу переважає над процесом мінералізації. У 2017 р. на варіантах 2 та 4 показник мінералізації вказує на переважання інтенсивності мінералізації органічних решток і як наслідок - зростання кількості елементів живлення. Зважаючи на середні показники коефіцієнтів мінералізації (див. табл. 2), на варіантах дослідних травосумішей процеси мінералізації протікають інтенсивніше, що вказує на вищий рівень активності мікрофлори порівняно 3 контрольним варіантом.

Табл. 1. Чисельність таксономічних груп мікроорганізмів у ризосфері трав на рекультивованих землях $2015-2017$ рр.

\begin{tabular}{|c|c|c|c|c|}
\hline $\begin{array}{c}\text { № } \\
\text { 3/п }\end{array}$ & Варіант досліду & Мікроміцети, тис. КУО/г & $\begin{array}{c}\text { Бактерії, що використовують мін. азот } \\
\text { (КАА) млн КУО/г }\end{array}$ & $\begin{array}{c}\text { Стрептоміцети, } \\
\text { млн КУО/г АСГ }\end{array}$ \\
\hline 1 & Варіант 1 & $17,86^{ \pm 0,26}$ & $4,28^{ \pm 0,47}$ & $1,77^{ \pm 0,07}$ \\
\hline 2 & Варіант 2 & $8,70^{ \pm 0,35}$ & $13,62^{ \pm 0,33}$ & $4,25^{ \pm 0,14}$ \\
\hline 3 & Варіант 3 & $19,44^{ \pm 0,39}$ & $8,07^{ \pm 0,73}$ & $2,80^{ \pm 0,09}$ \\
\hline 4 & Варіант 4 & $12,82^{ \pm 0,53}$ & $9,43^{ \pm 0,62}$ & $3,59^{ \pm 0,12}$ \\
\hline 5 & Контроль & $16,24^{ \pm 0,49}$ & $4,01^{ \pm 0,12}$ & $1,51^{ \pm 0,26}$ \\
\hline
\end{tabular}

Табл. 2. Спрямованість мікробіологічних процесів у ризосфері трав на рекультивованих землях 2015-2017 рр.

\begin{tabular}{|c|c|c|c|c|c|c|c|c|c|}
\hline \multirow{2}{*}{$\begin{array}{c}\text { № } \\
\text { 3/п }\end{array}$} & \multirow{2}{*}{ Варіант досліду } & \multicolumn{4}{|c|}{ Коефіцієнт мінералізації } & \multicolumn{4}{c|}{ Коефіцієнт оліготрофності } \\
\cline { 2 - 11 } & & 2014 & 2016 & 2017 & Середні & 2014 & 2016 & 2017 & Середні \\
\hline 1 & Варіант 1 & 6,33 & 0,31 & 0,62 & $\mathbf{2 , 4 2}$ & 0,06 & 19,69 & 0,15 & $\mathbf{6 , 6 3}$ \\
\hline 2 & Варіант 2 & 20,25 & 0,43 & 2,40 & $\mathbf{7 , 6 9}$ & 0,05 & 25,28 & 0,09 & $\mathbf{8 , 4 7}$ \\
\hline 3 & Варіант 3 & 16,17 & 0,25 & $0,90-$ & $\mathbf{5 , 9 5}$ & 0,05 & 23,61 & 0,17 & $\mathbf{7 , 9 4}$ \\
\hline 4 & Варіант 4 & 14,56 & 0,51 & 1,35 & $\mathbf{5 , 4 7}$ & 0,05 & 21,03 & 0,38 & $\mathbf{7 , 1 5}$ \\
\hline 5 & Контроль & 0,35 & 0,16 & 0,58 & $\mathbf{0 , 3 6}$ & 0,01 & 20,39 & 0,59 & $\mathbf{6 , 9 9}$ \\
\hline
\end{tabular}

Відповідно до динаміки показників мінералізації спостерігаємо зміни показників коефіцієнта оліготрофності (див. табл. 2). Так, коефіцієнт оліготрофності у рік закладання досліду - 2014, був нижчий від одиниці на всіх варіантах досліду, що свідчить про високий рівень забезпеченості рослин елементами живлення. У 2016 р. рослини всіх травосумішей активно розвивали вегетативну масу і мали показник оліготрофності досить високий, особливо на варіантах 2, 3, 4 порівняно 3 контрольною ділянкою досліду, що свідчить про низький рівень забезпеченості й активний розвиток оліготрофних організмів. У 2017 р. показники оліготрофності - нижче 1, як свідчення наростання вегетативної маси, активізації процесів мінералізації кореневих залишків та підняття рівня забезпеченості трав'яних рослин елементами живлення. Показники оліготрофності на дослідних варіантах $є$ значно нижчими за контрольну ділянку, 0,09-0,38 проти 0,59 на контролі.
Зважаючи на середні показники коефіцієнта оліготрофності на рекультивованих, після добування ільменітових руд, землях можливий досить активний розвиток як оліготрофних, так і евритрофних мікроорганізмів, що є свідченням нестабільності грунтового ценозу. У цьому плані за складу травосумішей: костричя очеретяна, стоколос безостий, грястиия збірна, конюшина червона, за рядкового посіву - варіант 2, відзначаємо найвищу амплітуду коливання.

На показники мікробної біомаси (табл. 3) визначальний вплив мали метеорологічні умови років досліджень. Проте, у міру розвитку 2014-2017 рр., агроценози дослідних варіантів за показниками мікробної біомаси переважають агроценоз проектного складу травосуміші (дані за 2017 р.).

Така ж сама тенденція за період дослідження 20142017 pp. - у динаміці показників "дихання грунту" дослідних ділянок (табл. 4).

Табл. 3. Вміст мікробної біомаси у кореневій зоні трав'яних рослин на рекультивованих землях у 2014-2017 pp.

\begin{tabular}{|c|c|c|c|c|c|c|}
\hline \multirow{2}{*}{$\begin{array}{c}\text { № } \\
\text { 3/п }\end{array}$} & \multirow{2}{*}{ Варіант досліду } & \multicolumn{5}{|c|}{ Біомаса мікроорганізмів, мкг С/г грунту } \\
\cline { 2 - 6 } & 2014 (вихідний) р. & $2015 \mathrm{p}$. & $2016 \mathrm{p}$. & $2017 \mathrm{p.}$ & Середні 2015-2017 рр. \\
\hline 1 & Варіант 1 & 76,95 & 722,73 & 356,21 & 675,20 & $369,453^{ \pm 6,36}$ \\
\hline 2 & Варіант 2 & 43,64 & 630,45 & 436,99 & 637,00 & $372,54^{ \pm 9,69}$ \\
\hline 3 & Варіант 3 & 54,14 & 736.41 & 391,64 & 644,85 & $363,54^{ \pm 5,47}$ \\
\hline 4 & Варіант 4 & 60,23 & 592,95 & 467,85 & 637,78 & $388,62^{ \pm 8,57}$ \\
\hline 5 & Контроль & 124,56 & 696,18 & 461,01 & 599,36 & $394,97^{ \pm 6,45}$ \\
\hline
\end{tabular}


Табл. 4. Інтенсивність дихання у кореневій зоні трав'яних рослин на рекультивованих землях у 2014-2017 рр.

\begin{tabular}{|c|c|c|c|c|c|c|}
\hline \multirow{2}{*}{$№$} & \multirow{2}{*}{ 3/п } & \multirow{2}{*}{ Варіант досліду } & \multicolumn{5}{|c|}{ Інтенсивність виділення $\mathrm{CO}_{2}$ мкг СО $\mathrm{CO}_{2} /$ г грунту } \\
\cline { 2 - 6 } & 2014 (вихідний) р. & $2015 \mathrm{p}$. & $2016 \mathrm{p}$. & 2017 р. & Середні 2015-2017 рр. \\
\hline 1 & Варіант 1 & 28,70 & 21,3 & 7,10 & 8,87 & $14,89^{ \pm 0,69}$ \\
\hline 2 & Варіант 2 & 20,37 & 28,6 & 9,67 & 11,29 & $13,78^{ \pm 0,42}$ \\
\hline 3 & Варіант 3 & 20,17 & 35,9 & 6,24 & 9,24 & $11,88^{ \pm 0,40}$ \\
\hline 4 & Варіант 4 & 27,78 & 26,4 & 5,96 & 9,03 & $14,26^{ \pm 0,98}$ \\
\hline 5 & Контроль & 33,61 & 29,3 & 5,55 & 8,27 & $15,81^{ \pm 0,34}$ \\
\hline
\end{tabular}

Якщо на початок закладання досліду інтенсивність дихання у кореневій зоні контрольного, не порушеного агроценозу проектної травосуміші, була вищою від показників дослідної ділянки, в середньому на 20-28 проти 33,6 мкг $\mathrm{CO}_{2} /$ г грунту, то в міру розвитку цих агроекосистем ця пропорція змінилась на користь дослідних варіантів. Емісія вуглекислого газу на дослідних ділянках у 2017 р. є вищою від контрольного варіанта, що свідчить про вищий рівень мікробіологічної активності в ризосфері дослідних травосумішей на рекультивованих ділянках.

Поряд $з$ цим, відповідно до наших досліджень, на порушених грунтах Яворівського та Новороздільського сірчаних кар'єрів відзначено, що зростання видового різноманіття рослин сприяє також збагаченню мікологічної структури грунтів. Так, структурними родами для плеяд грибів у грунтах Яворівського сірчаного кар'єру серед меланінвмісних видів були види роду Aureobasidium та Cladosporium. Окрім меланінвмісних таку ж функцію виконували світлопігментовані види родів $A s$ pergillus, Fuzarium, Penicillium, Rhizopus. На пробних площах у межах Новороздільського сірчаного кар'єру на рівні $r=1,0$ сформувались високоорганізовані грибні комплекси, які описуються плеядами "ліхтарик", тричленна та інші. У складі таких плеяд переважали структурні види родів світлозабарвлених грибів Aspergillus, Penicillium, Fuzarium, Trichoderma, Mисоr, і меншою мірою із меланінвмісних мікроміцетів були представлені види родів Aureobasidium та Cladosporium [7, 8].

Відзначено, що найвищою біологічною різноманітністю 50 видів мікроміцетів 3 високою частотою трапляння Aureobasidium pullulans (23,1\%), Trichoderma lignorum $(12,5 \%)$ характеризуються порушені землі Новороздільського сірчаного кар'єру, на яких створені мішані деревостани. Дещо меншою різноманітністю (43 види) характеризується мікобіота грунтів 3 високою частотою трапляння Penicillium digitatum (31,5\%), Aureobasidium pullulans $(18,5 \%)$ на території Яворівського сірчаного кар'єру, де видовий склад деревостанів значно спрощений $[7,8]$.

\section{Висновки}

Зазначено, що на рекультивованих після добування ільменітових руд землях можливий досить активний розвиток, як оліготрофних, так і евритрофних мікроорганізмів, що є свідченням нестабільності грунтового ценозу.

Відзначено, що на варіантах дослідних травосумішей процеси мінералізації протікають інтенсивніше, що вказує на вищий рівень активності мікрофлори, порівняно $з$ контрольним варіантом.

Досліджено, що емісія вуглекислого газу на дослідних ділянках є вищою від контрольного варіанта, що свідчить про вищий рівень мікробіологічної активності в ризосфері дослідних травосумішей на рекультивованих ділянках.
Результати здійсненого аналізу мікробіологічної активності у ризосфері дослідних травосумішей засвідчує, що показники мікробіологічної активності є вагомими критеріями в оцінюванні процесів реабілітації порушених земель та визначенні ефективності прийомів на біологічному етапі рекультивації земель після добування ільменітових руд.

Проаналізовано, що на порушених грунтах Яворівського та Новороздільського сірчаних кар'єрів зростання видового різноманіття рослин сприяє збагаченню мікологічної структури грунтів.

Встановлено, що найвища біологічна різноманітність (50 видів) характерна для порушених земель Новороздільського сірчаного кар'єру, на яких створені мішані деревостани, менша різноманітність (43 види) для мікобіоти грунтів на території Яворівського сірчаного кар'єру, де видовий склад деревостанів значно спрощений.

\section{References}

1. Aliev, I. N. (2012). Estestvennoe oblesenie i biologicheskaia rekultivatciia narushennykh zemel Severnogo Kavkaza (na primere Kabardino-Balkarii). Abstract of Candidate Dissertation for Agricultural Sciences (06.03.01 - Forest crops and Phytomelioration). Volgograd, 42 p. [In Russian].

2. Andreiuk, K. I., Iutynska, H. O., Antypchuk, A. F., et al. (2001). Functioning of microbial coenoses of soil in the conditions of anthropogenic loading. Kyiv: Charms, 240 p. [In Ukrainian].

3. Babeva, I. P., \& Zenova, G. M. (1989). Biologiia pochv: tutorial. (D. G. Zviagintceva Scientific Ed.). Moscow: Publishing house of Moscow State University, 336 p. [In Russian].

4. Bashkatov, V. G., Torokhova, O. N., Zhukov, S. P. (2002). Rekomendatcii po formirovaniiu meliorativnogo rastitelnogo pokrova na otvalakh ugolnykh shakht Donbassa: prakt. rekomendatcii. Donetck, 36 p. [In Russian].

5. Borysiuk, B. V., Demianchuk, L. S., \& Bunas, A. A. (2013). Vplyv rehuliatoriv rostu roslyn na aktyvnist mikroflory korenevoi zony roslyn khmeliu. Agroecological journal, 3, 70-74. [In Ukrainian].

6. Dospekhov, B. A. (1985). Metodika polevogoopyta (s osnovami statisticheskoi obrabotki rezultatov issledovanii): tutorial. (5th ed. add. and revised). Moscow: Agropromizdat, 351 p. [In Russian].

7. Kopii, M. L., \& Oliferchuk, V. P. (2016). Mikolohichna struktura gruntu v mezhakh sformovanykh ekotopiv porushenykh landshaftiv Yavorivskoho sirchanoho karieru. Scientific Bulletin of UNFU, 26(1), 174-181. [In Ukrainian].

8. Kopii, M. L., Oliferchuk, V. P., \& Kopii, L. I. (2016). Vydove riznomanittia mikromitsetiv gruntu terytorii Novorozdilskoho sirchanoho karieru. Scientific Bulletin of UNFU, 26(3), 278-287. [In Ukrainian].

9. Mekich, M. Z., Dzhura, N. M., \& Terek, O. I. (2013). Funktsionalne i prykladne znachennia biolohichnoi aktyvnosti gruntu. Studia Biologica, 7(3), 247-258. [In Ukrainian].

10. Metody pochvennoi mikrobiologii i biokhimii. (1991). (D. G. Zviagintceva Scientific Ed.). Moscow: Publishing house of Moscow State University, 304 p. [In Russian].

11. Microbiological methods for assessing soil quality. In: Bloem J., Hopkins D. W., Benedetti A. (Ed.). (2005). Wallingford: CABI Publishing, 307 p. 
12. Tepper, E. Z., Shilnikova, V. K., \& Pereverzeva, G. I. (1993). Praktikum po mikrobiologii. Moscow: Kolos Publishing House, 175 p. [In Russian].
13. Volkohon, V. V. (2012). Mikrobiolohichni aspekty vidtvorennia rodiuchosti gruntiv. Bulletin of Agricultural Science, 9, 9-14. [In Ukrainian].

B. V. Borysyuk ${ }^{1}$, V. V. Shvets ${ }^{1}$, M. L. Kopiy ${ }^{2}$

${ }^{I}$ Zhytomyr National Agroecological University, Zhytomyr, Ukraine ${ }^{2}$ Ukrainian National Forestry University, Lviv, Ukraine

\section{MICROBIOLOGICAL ACTIVITY IN THE GRASSMIXTURE RHIZOSPHERE ON RECLAIMED LANDS}

The influence of the structure and method of grassmixture sowing on the biological activity and mycological structure of reclaimed soil on different research plots is considered. It is noted that there is constant mutual beneficial biotic correlation between microflora and plants, which is reflected in the growth of physiological groups of microorganisms number in rhizosphere. Root excretions of plants specifically effect on microorganisms development of root zone and biochemical activity of soil. The research has revealed the advantage of increasing the number of bacteria using mineral nitrogen and streptomycetes in variant of grassmixture: Phalaris arundinacea, Dactylis glomerata, Trifolium pratense, both for row sowing and for scattering. On experimental samples of grassmixtures mineralization processes are noted to be more intensive, respectively, the level of microflora activity is much higher compared to design composition. The average indicators of mineralization coefficients on the samples of experimental grassmixtures indicate that mineralization processes are more intense, what means that the level of microflora activity is higher compared to control variant. Judging by the average indicators of oligotrophic coefficient on reclaimed lands after ilmenite ores extraction, both oligotrophic and eurytrophic microorganisms can develop quite actively, that proves instability of the soil coenosis. The meteorological conditions of research years had a decisive influence on microbial biomass indicators. However, during 2014-2017, the agrocenoses of experimental variants in terms of microbial biomass prevail the agrocenosis of the design grassmixture composition (data for 2017 year). Carbon dioxide emission on the experimental plots in 2017 are higher than control variant, that indicates a higher level of microbiological activity in rhizosphere of experimental grassmixtures on reclaimed plots. In accordance to dynamics of mineralization indicators, we observe changes of oligotrophic coefficient indicators. During the development of agrocenosis of experimental variants, the agrocenosis of design composition of grassmixture is proved to prevail in terms of microbial biomass. The research shows that the growth of plant species diversity also contributes to mycological structure of soils enrichment on disturbed soils of Yavoriv and Novyj Rozdil sulfur quarries. It is noted that the highest biological diversity of 50 species of micromycetes with a high frequency of Aureobasidium pullulans (23.1\%), Trichoderma lignorum (12.5\%) are characterized by disturbed lands of Novyj Rozdil sulfur quarry, on which mixed stands are created. Slightly less diverse (43 species) is appropriate for mycobiota of soils with a high frequency of Penicillium digitatum (31.5\%), Aureobasidium pullulans (18.5\%) in Yavoriv sulfur quarry, where the species composition of stands is significantly simplified.

Keywords: grassmixture; plant communities; rhizosphere; biological stage of reclamation; bacteria; mineralization; mycological structure. 